Modern Asian Studies 52, 3 (2018) pp. 1043-1075. (C) Cambridge University Press 2018 doi:10.1017/Soo26749X1600o937

\title{
From (Violent) Protest to Policy: Rearticulating authority through the National Youth Policy in post-war Nepal
}

\author{
AMANDA SNELLINGER \\ University of Washington \\ Email:ats35@uw.edu
}

\begin{abstract}
Youth frustration was a front-running issue during Nepal's decade-long civil war (1996-2006) and democratic protests (2003-2006). Young activists were mobilized as foot soldiers in these political battles, but they also capitalized on their position to establish themselves politically. They earned public recognition for their direct action; however, they have struggled to stay relevant as their parties shifted from protesting against the government to running the government. In response, youth activists leveraged the public support they earned and general concern over youth disenfranchisement to demand an active role in state restructuring. The Maoist-majority Constituent Assembly government partially heeded them by handing over the task of drafting the National Youth Policy to their youth wings and other youth activists. This policy shaped the youth-focused agenda of the newly designed Ministry of Youth and Sports and other government bureaus. This article uses the National Youth Policy as the context for an examination of how youth activists are establishing public authority beyond (violent) protest. By focusing on the micro-politics of the committee appointed to draft the Policy, I analyse the techniques its members used to assert their political values and agendas through policymaking in order to secure their positions during politically turbulent times. This article elucidates how formalized governing practices and revolutionary politics blend to reconstitute state order in the aftermath of civil war.
\end{abstract}

\section{Introduction}

In 2006, ten years after the Maoists declared war on the state and four years after the political parties began protesting against the king's dismissal of their elected government, Nepal began its transition from a Hindu constitutional monarchy to a secular, democratic 
republic. Youth activists played a central role in turning the political tide through their tireless dedication: organizing street protests, combating the state Army in the hinterlands, and mobilizing the public to support their parties against the king. They felt ownership over this politically contentious period because they were very much the face of it, and they established public authority by critiquing the political status quo and offering themselves as a future alternative. ${ }^{1}$ After the king stepped down and their political parties became the caretakers charged with restructuring 'new Nepal', these young activists were eager to transition into new roles from activists to politicians, and move off the streets and into a legitimate space in the government they had made possible. Some of the most popular youth leaders progressed into mainstream politics successfully, but this was on an individual basis. Institutionally, there was no clear path for this youth cohort to advance, until 2008 when they were granted an opportunity by the Maoist majority government to draft the National Youth Policy (NYP).

Establishing the NYP was integral to Nepal's post-conflict agenda, wherein 'new rules of the game are negotiated'. ${ }^{2}$ Post-war authority was being negotiated on multiple levels and venues. Actors with varying political backgrounds and agendas came together to reestablish who would assert authority and in what contexts. This article focuses on political youth activists' efforts to legitimize their role in Nepal's post-war political landscape. I demonstrate how they co-opted the drafting of the NYP in order to ensure a role in overseeing the flow of youth-allocated resources in the new government. Through such efforts youth activists were establishing their authority beyond (violent) protest. I detail how they leveraged the public support they earned during the war and political movements (andolan) as well as the general concern over youth disenfranchisement in order to secure a sphere in which they hoped to govern.

These youth activists' role in post-conflict policy formation produced a particular type of public authority dynamic, which was simultaneously similar to authority during their political movements and radically different. I suggest that their shift from violent contestation on the streets and jungles to negotiating policy

\footnotetext{
${ }^{1}$ A. Snellinger, 'Let's See What Happens': Hope, Contingency, and Speculation in Nepali Student Activism', Critical Asian Studies, vol. 48(1), 2016, pp. 27-49.

${ }^{2}$ Cf. S. Byrne and B. Klem. 'Constructing Legitimacy in Post-war Transition: The Return to “Normal” Politics in Nepal and Sri Lanka?', Geoforum, vol. 66, 2015 , pp. 224-233.
} 
in bureaucratic settings serves as a case study that elucidates how revolutionary politics and formalized governing practices blend together to reconstitute state order in post-war contexts. Furthermore, the youth activists' limited success demonstrates why certain entrenched power dynamics endure despite radical shifts in institutional power arrangements. The limits they came up against while formally participating in policymaking echo a history of disillusionment experienced by Nepali political activists after governing falls short of the promised change for which they fought. Such disappointment has propelled political parties to oscillate between revolting against the state to being the state over the last 60 years. Instead of dismissing Nepal's political history as a series of successes and failures, ${ }^{3}$ I contend that it is more illustrative to frame this political history as a radical democratic process and constant negotiation over meaning, agenda, and direction to order social relations. ${ }^{4}$ The political parties have undertaken this negotiation with a pendulum-like momentum, swinging between political movements (andolan) and governing. They derive public authority from what they have achieved during the andolan and this becomes the basis from which to establish a new ruling order, over and over again.

To understand the nuances of the public authority dynamic within the scope of this article, it is important to understand the sociopolitical dimensions of youth both within academic debates and in Nepali politics. 'Youth' is a useful sociological category because it points to the 'topography of power relations' within a given empirical context. 'Youth' is considered to be a contentious category because of the way it is discursively employed by those in varying socio-political positions to empower, assert, legitimize, mobilize, or

\footnotetext{
${ }^{3}$ Framing Nepal's transitional politics as a radical democratic process allows me to avoid the pitfalls of a common 'foreign interventionist' narrative that pathologizes Nepal's 'state fragility' in an ahistorical manner without acknowledging the role of external actors in co-constructing governance in Nepal. See S. Tamang, 'Historicizing State Fragility in Nepal', Studies in Nepali History and Society, vol. 17(2), 2012, pp. $263-295$.

${ }^{4}$ Ernst Laclau and Chantal Mouffe argue that since any social order is a specific pattern of power relations, then politics needs to be seen as constituting the identities of those who engage it. See E. Laclau and C. Mouffe, Hegemony and Socialist Strategy, London, Verso, $19^{8} 5$.

${ }^{5}$ J. Chua, 'Making Time for the Children: Self-Temporalization and the Cultivation of the Antisuicidal Subject in South India', Cultural Anthropology, vol. 26(1), 201 1, pp. $112-137$.
} 
marginalize young people. ${ }^{6}$ As transnational and national policy agendas increasingly focus on youth, discursive negotiations between culturally specific definitions of youth and universal notions have made youth an even more flexible category of the social that is continually being contested and renegotiated by a number of individuals both within and between societies. Furthermore, youth has been an integral aspect of post-colonial politics in South Asia as it has determined how participation, recruitment, and leadership are broadly understood in social and political movements throughout the continent. ${ }^{7}$

I have argued elsewhere that the category of youth in Nepali politics is a mixture of modernity - an age hierarchy grounded in the cultural tenets of the Hindu life cycle-and post-modernitya contested category of being and becoming. ${ }^{8}$ The particular form youth takes in politics differs from general Nepali society. In general society, youth (yuba) is broadly defined by the socio-bureaucratic category (the age demographic of $15^{-29}$ ) and the socio-cultural category based on life stage factors (before parenthood or position of responsible householder). Nepali young people embody this semantic range as they navigate official and intimate contexts. The category of 'youth' in Nepali politics, however, has expanded beyond the generally accepted age range of $15^{-29}$ to incorporate more generations as opportunities for leadership positions have diminished. This has created an internal hierarchy within the political youth demographic itself as people try to claim authority and garner influence within

${ }^{6}$ Cf. M. Bucholtz, 'Youth and Cultural Practice', Annual Review of Anthropology, vol. 31, 2002, pp. 525-552; D. Durham, 'Disappearing Youth: Youth as a Social Shifter in Botswana', American Ethnologist, vol. 31 (4), 2004, pp. 589-605; A. Snellinger, 'Shaping a Liveable Present and Future: Review of Youth Studies in Nepal', European Bulletin of Himalayan Research, vol. 42, 2013, pp. 75-104.

${ }^{7}$ Cf. M. Andersen, 'The Politics of Politics: Youth Mobilization, Aspirations and the Threat of Violence at Dhaka University', PhD thesis, Copenhagen University, Denmark, 2013; T. Hansen, 'Recuperating Masculinity: Hindu Nationalism, Violence, and the Exorcism of the Muslim "Other", Critique of Anthropology, vol. 16(22), 1996, pp. 137-172; D. Hughes, Violence, Torture, and Memory in Sri Lanka: Life After Terror, Abingdon and New York, Routledge, 2013; C. Jeffrey, Timepass: Youth, Class, and the Politics of Waiting in India, Stanford, Stanford University Press, 2010; A. Sen, Shiv Sena Women: Violence and Communalism in a Bombay Slum, Bloomington, Indiana University Press, 2007; B. Suykens, “A Hundred Per Cent Good Man Cannot do Politics”: Violent Self-sacrifice, Student Authority, and Party-state integration in Bangladesh' in this special issue; A. Snellinger, "Yuba, Hamro Pusta!": Youth and Generational Politics in Nepali Political Culture', Studies in Nepali History and Society, vol. 14(1), 2009, pp. 39-66; O. Verkaaik, Migrants and Militants: Fun and Urban Violence in Pakistan, Princeton, NJ, Princeton University Press, 2004.

"Snellinger, "Yuba, Hamro Pusta!". 
party structures where it is becoming increasingly difficult to arrive to power. Thus in Nepali politics, youth is a relational category that is contextually contingent. This article elucidates how these so-called young politicians instrumentally employ the category of youth to mediate power relations and garner public authority within the sociopolitical constraints they face.

The argument of this article is based on an analysis of policy and supporting documents, and focused interviews I undertook in 2013 and 2015 with people who participated in or closely observed the NYP development process and earlier government youth-focused policy initiatives. I interviewed ten Drafting Committee members who were selected to represent a diverse range of demographics and interests; five high-level bureaucrats from the Ministry of Youth and Sports (MYS) and three from the Youth Small Enterprise and SelfEmployment Fund (YSEF); the head of His Majesty's Government's (HMG) 1996 high-level commission report assessing the youth situation; a Lead International project coordinator who was contracted by the Norwegian government to organize leadership programmes and produce reports; a representative from the UN Development Fund for Women (UNIFEM); a UN Population Fund (UNFPA) coordinator who oversees Nepal's Youth Advisory Panel (YAP); a Save the Children programme officer who worked closely with the MYS to institute the NYP; and the country director of the International Labour Organization (ILO). As demonstrated throughout this article, the Drafting Committee members were active agents who infused the policy and its institution with their vision of 'new Nepal', albeit under specific structural and discursive constraints of state and transnational regimes.

Although I factor in the views of all the Drafting Committee participants, my analysis focuses on the strategies of the political youth wings in order to interrogate the dimensions of public authority through the shift from contentious politics to governing in postconflict contexts. The following two sections establish the backdrop to understand the political youth wings' agenda while drafting the youth policy. The first of these frames Nepal's political history as a pendulum that swings between activism and governing within the parameters of radical democratic theory. It sketches the sociocultural context needed to understand the central role of patronage and resource allocation in establishing and maintaining governing authority. The second section places the government's investment in youth policy within the post-conflict transition that the post-peace 
talks government undertook with the United Nations' Mission in Nepal (UNMIN). It demonstrates how the new government used the drafting of the NYP to garner political capital both with international entities by presenting it as a peace-building intervention and with their political youth activists by providing them with a role in state restructuring. The next two sections demonstrate how the politically oriented youth members of the NYP Drafting Committee used the policy to establish a new platform for themselves which they hoped would ensure their ability to oversee policy and resource distribution. The third section demonstrates how the political youth activists' agenda limited the NYP to being a political document rather than a policy document that could be put into practice, thus curtailing their governing aspirations. The fourth section analyses the debate over the age range that defines youth in the policy and the stakes in defining youth as an administrative category. The penultimate section highlights the limits of policy formation as a mechanism to accrue such public authority. These young politicians' entrée into formalized participatory politics was an inclusive overture. However, they faced disillusionment as they came to understand that their participation in policy formation was a mere token, part of the postconflict agenda meant to ensure stability during post-war transition. Ultimately, instituting the policy is the purview of MYS bureaucrats who simultaneously want to maintain their own sphere of influence while also experiencing pressure from donors, civil society, and competing political agendas.

The vying political, civil society, and bureaucratic agendas over the NYP are constitutive of the struggle for public authority in Nepal's newest iteration of state restructuring. The outcomes highlight the limits inherent in trying to institute political aspirations through state mechanisms which are being reshaped in a post-war context with oversight from international aid agencies.

\section{Public authority: a pendulum between democracy and post-democracy}

For the political youth leaders the stakes inherent in drafting the NYP demonstrate the close relationship between contentious politics and governing in Nepali political history, which is a product of the way in which representational politics has unfolded in the country. Since the $195^{\circ}$ s Nepali politics has been defined by its 
struggle for multiparty democracy. In 1950, with support from the Indian government, democratic parties joined King Tribhuvan Bir Bikram Shah to overthrow the Rana regime. King Tribhuvan supported multiparty democracy, but party squabbling resulted in little progress being made towards instituting any liberal reforms. This soured Prince Mahendra Bir Bikram Shah who, in 196o, soon after his coronation, ended the party experiment and established the Panchayat system of monarchical one-party rule. The system was a mix of local-level elections and appointments made by the king's Pancha Council. All other parties were banned, forcing multiparty democratic activists underground for 30 years. Multiparty democracy under a constitutional monarchy was re-established after the success of the 1990 People's Movement (jana andolan). By 1996, however, it became apparent that liberal democracy had not brought the equitable resource and opportunity distribution expected, so the Maoists abandoned the parliamentary project for armed revolution. The Maoists People's War (1996-20o6) led to the loss of over 17,000 lives. After two major Army campaigns failed to stem Maoist expansion the government brokered peace talks in 2001. When these talks fell apart, the king dismissed the elected parliament, using Article 127 of the Constitution to justify his intervention to protect the nation's security. Meanwhile, multiparty activists launched the 'Movement against Regression' (2002-2006), demanding the reinstatement of the elected government. The Maoists and seven political parties eventually united in 2005. Together they led the 2006 mass movement (the second jana andolan) that dethroned the king. Peace talks were brokered, an interim all-party government was established, Nepal was declared a democratic secular republic, and Constituent Assembly (CA) elections were held in 2008. All this took place with the assistance of the United Nations' Mission in Nepal (UNMIN).

Jacques Rancière's theory of radical democracy provides a framework to understand Nepal's tumultuous political history as an iterative process. ${ }^{9}$ Rancière critically deconstructs the components of normative democratic theory in order to interrogate representational democracy's inability to accommodate the multiplicity of voices within the polis. The ways in which decisions are made, resources are collected and redistributed, and governing mechanisms operate in

${ }^{9}$ J. Rancière, 'What is the Subject of the Rights of Man?', South Atlantic Quarterly, vol. 103(2-3), 2004, pp. 297-310; J. Rancière, Disagreement: Politics and Philosophy, J. Rose (trans.), Minneapolis, University of Minnesota Press, 1999. 
representative democracy are determined by a socially dominant logic, which is rarely inclusive. He terms this the 'policing logic'-the way things are structurally distributed among social groups, how public space is configured, and who has a voice in it. Democratic governments establish structures and institutions that formalize the 'policing logic' and political participation is restricted to protect the order of things from the process of politics. Politics, as Rancière asserts, 'is an inquiry into the distribution of spaces. It asks, "What are these places? How do they function? Why are they here? Who can occupy them?" 10 The intent of normative democratic order is to remove the agonism that politics engenders. Thus Rancière refers to normative democratic governance as 'post-democracy' and defines 'democracy' as political action that aims to disrupt the 'policing logic' by rendering it visible and asserting alternatives in the way public life can be structured.

Framed within Rancière's theoretical paradigm of radical democracy, the andolan in Nepal's political history plays the role of 'democracy'. Through political movements, party activists have appealed to the public to reject the current 'policing logic' of the ruling elite and embrace their demands for an alternative political system that will ensure socio-economic justice and inclusion. ${ }^{11}$ In $195^{1,} 1991$, and then in 2007, having secured popular support and overthrown the ruling governments, the political parties shifted into the stage of 'post-democracy' when they attempted to broker authority through electoral politics and consensual deliberation on behalf of all citizens, whose voices had been reduced to an equal, albeit unrecognized, vote. Nepal's state-restructuring process followed the classic 'postdemocratic' stage in which All Party Mechanisms were embraced as ways to govern, from the local level up to drafting the Constitution, in order to maintain peace during the post-war transition. ${ }^{12}$ All parties, including the Maoists, opted for 'conflict-free' politics. ${ }^{13}$

${ }^{10}$ J. Rancière, The Politics of Aesthetics: The Distribution of the Sensible, London, Continuum, 2003, p. 201.

${ }^{11}$ Snellinger "Let's See What Happens".

${ }^{12}$ Cf. S. Byrne and G. Thapa, 'A Compromising Consensus?: Legitimizing Local Government in Post-conflict Nepal', International Development Planning Review, vol. 36(4), 2014, pp. 435-453; A. Snellinger, 'The Production of Possibility Through an Impossible Ideal: Consensus as a Political Value on Nepal's Constituent Assembly', Constellations, vol. 22(2), 2015, pp. 233-245.

${ }^{13}$ D. Hirslund, 'The Politics of Post-conflict Democratization: Justice and Insurgency After the War', Hot Spots, Cultural Anthropology, 24 March 2014, http://www.culanth.org/fieldsights/5o8-the-politics-of-post-conflict-democratizationjustice-and-insurgency-after-the-war, [accessed 28 February 2018]. 
As early as 1977, Lok Raj Baral noted that governing in Nepal was a 'permanent transition'. ${ }^{14}$ More recently, others have described Nepal's political situation as one of long-term provisionality, ${ }^{15}$ involving 'adhoc governing, ${ }^{16}$ because a political economy of transition serves the 'power polygon' comprising the ruling elite, oppositional parties, civil society, business groups, and international agencies. ${ }^{17}$ Thus Nepal's history of political parties coming in and out of government demonstrates the complexity their public authority engenders as both anti-establishment and establishment. Political actors leverage the transgressive agendas they raised during andolan as their mandate to govern. And in turn politicians use their positions as guardians of the democratic state to establish influence in an array of institutions to entrench their public authority.

This entrenchment of public authority through governing was particularly apparent after the reinstitution of multiparty democracy opened up the political field in 1990. Political party members sought to usurp influence and gain authority at all levels of governance, from which they had been excluded for 30 years. They did not limit themselves to state apparatuses, but instead intruded into all spheres of local public life to establish themselves as the 'neutral authority of the state'. ${ }^{18}$ One of the key ways they did this was by replacing the traditional elites-the tax collector, the pancha bhaladami (mediator/social worker), pradhan panch (local mayors), and (later on) community school committees-and their role in resolving local disputes and problems. ${ }^{19}$ Bert Suykens and Danielle Stein emphasize this trend in their analysis of dispute settlement at the local level

${ }^{14}$ L. R. Baral, Oppositional Politics in Nepal, Kathmandu, Himal Books, 2006 [1977].

${ }^{15}$ H. Hindman, 'Post-political in the Post-conflict: DIY Capitalism, Anarchoneoliberalism and Nepal's Ungovernable Mountains', Hot Spots, Cultural Anthropology, 24 March 2014, http://www.culanth.org/fieldsights/507-post-politicalin-the-post-conflict-diy-capitalism-anarcho-neoliberalism-and-nepal-s-ungovernablemountains, [accessed 28 February 2018 ].

${ }^{16}$ S. Byrne, "From Our Side Rules Are Followed": Authorizing Bureaucracy in Nepal's "Permanent Transition" in this special issue.

${ }^{17}$ A. J. Nightingale, A. Bhattarai, H. R. Ojha, T. S. Sigdel and K. N. Rankin, 'Fragmented Public Authority and State Un/making in the "New" Republic of Nepal' in this special issue.

${ }^{18}$ Bert Suykens and Bart Klem, 'The Politics of Order and Disturbance: Public Authority, Sovereignty, and Violent Contestation in South Asia' in this special issue.

${ }^{19}$ K. Hachhethu, 'Local Democracy and Political Parties in Nepal: A Case Study of Dhanusha District'. In Local Democracy in South Asia: Microprocesses of Democratization in Nepal and its Neighbour, D. Gellner and K. Hachhethu (eds), London, Sage, 20o8, pp. 45-70; R. Edwards, 'Disconnect and Capture of Education Decentralisation Reforms 
wherein 'adjudicating disputes continues to be an important factor in shaping the public image and authority of Nepal's newly dominant authority figures: political parties'. ${ }^{20}$

The democratic government's expansion of the state-through gatekeeper bureaucrats who provided services and political party leaders who distributed funds and asserted influence locally-further legitimized the multiparty system. ${ }^{21}$ This created a positive feedback loop between 'resource governance'22 and public authority, wherein 'authority is made visible ... in decision-making processes about access to resources'. ${ }^{23}$ Access to state and public resources and having the influence to dictate their distribution is key to establishing and maintaining authority as a political institution (i.e. multiparty politics), as a party, and personally.

Thus patronage and resource allocation are central factors in vying for government power and influence in public spheres. A student leader emphasized this mutually reinforcing dynamic between authority, patronage, and resource allocation when he asserted that 'politics is glamour'. ${ }^{24}$ I asked him what he meant and he clarified, 'It is difficult to become a leader. But once you arrive to power there is honour [ijjat]. People will follow he who has power and resources. And this is the reason people are attracted to politics. ${ }^{25}$ This student leader's explanation demonstrates the reciprocal dynamic of patronage found throughout South Asia. It is not a one-way dynamic but a give-and-take that is established through obligation. ${ }^{26}$

In Nepal's context, the ability to 'arrive to power' and the accompanying prestige only became a common dimension of political party participation after 1990. Multiparty politics professionalized political participation, opening up career opportunities that were

in Nepal: Implications for Community Involvement in Schooling', Globalisation, Societies and Education, vol. 9(1), 201 1, pp. 67-84.

${ }^{20}$ B. Suykens and D. Stein, 'Neutrality, Party Politics, and Mediation in Central and West Terai, Nepal', Report for the Asia Foundation/Justice and Security Research Programme, 2014.

${ }^{21}$ J. Pfaff-Czarnecka, 'High Expectations, Deep Disappointments: Politics, State, and Society in Nepal after 1990'. In Himalayan People's War: Nepal's Maoist Rebellion, M. Hutt (ed.), Bloomington, Indiana University Press, 2004, pp. 166-19o.

${ }^{22}$ Nightingale et al., 'Fragmented Public Authority'.

${ }^{23}$ Byrne, "“From Our Side Rules Are Followed".

${ }^{24}$ This interviewee used the English word 'glamour'.

${ }^{25}$ Translation from an interview with an Nepal Student Union (Democratic) (NSU (D)) central committee leader, 15 November 2003.

${ }^{26}$ A. Piliavsky (ed.), Patronage as Politics in South Asia, Cambridge, Cambridge University Press, 2015 . 
not available when the political parties were underground during the Panchayat era. ${ }^{27}$ Similarly the Maoists experienced increased enrolment after their 2008 CA victory. ${ }^{28}$ Cadre ranks increased rapidly, which redefined the party hierarchy and relations between political wings within the larger party structure. A Nepali Congress leader explained to me that before multiparty democracy, there was the new generation and the old generation. But with the combination of the leaders refusing to retire and increased cadre enrolment, this simple distinction between old and young no longer represents political reality. Now, he claims, there are over four generations in politics, all at different ranks or 'period [s] of waiting' ${ }^{29}$ This scarcity of positions has forced political cadres at all levels to establish their own niche to eke out whatever influence, authority, and resources they can within the political structure. The political youth activists' motivations when drafting the NYP need to be understood in this context.

The drafting of the NYP in 2008 occurred early in the political transition from andolan to governing during this iteration of the Nepali state. The Constituent Assembly government was enshrining a new governing logic through drafting a new Constitution and state restructuring. The political youth leaders were eager to participate in 'making new Nepal' through the National Youth Policy for three reasons: to legitimize their political relevancy beyond being the parties' foot soldiers, to dictate the terms of what 'youth' entailed in a bureaucratic setting, and to establish themselves as the caretakers of the youth demographic. The political youth leaders approached drafting the NYP in a traditional way by usurping the process to carve out their own sphere of influence, which they hoped to maintain through resource allocation and distribution. Their attempt to reposition their legitimacy as youth activists underscores how public authority is ever-shifting in developing democratic states, constantly being renewed and negotiated in different venues and contexts, albeit often by an entrenched nexus of influential actors.

${ }^{27}$ A. Snellinger, Making New Nepal: From Student Activism to Mainstream Politics, Seattle, University of Washington Press, 2018.

${ }^{28}$ A. Adhikari, The Bullet and the Ballot Box: The Story of Nepal's Maoist Revolution, London, Verso, 2014; K. Hachhethu, 'The Community Party of Nepal (Maoist): Transformation From an Insurgency Group to a Competitive Political Party', European Bulletin of Himalayan Research, vol. 33-34, 2009, pp. 39-71; A. Snellinger, 'The Young Political Generation Today, Five Years Later', Himalaya, vol. 31(1-2), 2009, pp. 6162.

${ }^{29}$ Snellinger, "'Yuba, Hamro Pusta!"”. 


\section{Post-conflict transition: 'mobilizing youth to rebuild the nation'}

The drafting and institution of the NYP was a direct effort to establish state legitimacy within the post-conflict agenda. In cooperation with the United Nation's Mission in Nepal (UNMIN), Nepal officially embarked upon a post-conflict transition, meant to ensure stability and peace. The standardized strategy created by the United Nation's peace-building commission shaped this post-conflict intervention. ${ }^{30}$ The procedure involved foreign actors supplying security and investment in an attempt to create stability and encourage local communities to invest locally and, ultimately, reinforce state legitimacy. ${ }^{31}$ The role foreign actors have played in legitimating governing practices in post-war Nepal is clearly exemplified by the drafting of the NYP.

Reaching out to the youth demographic was a central component of state restructuring because transnational development, donors, and state-building agencies directly linked investment in opportunities for youth with peace and stability. The decade-long civil war between the government and Maoists (1996-2006) and the ongoing democratic street protests since $\mathbf{2 0 0 3}$ made it clear that the youth were disgruntled and frustrated with their lack of prospects in Nepal. They were simultaneously the political forces' strongest asset and most dangerous liability. All factions mobilized these young people in their political battles. It was very widely agreed that the 'youth issue' had to be addressed, aptly put by a CA member as follows: 'the NYP agenda is directly linked with political stability'. ${ }^{32}$ For this reason, the NYP had multiparty support.

The NYP was drafted in response to an Interim Constitution provision urging the government to adopt policies that would mobilize youth in the peace process. The 2007 Three-Year Interim Plan (TYIP) outlined a long-term vision to 'make youth major partners in the nation by emphasizing their role in the social, cultural and economic development of the nation and establishment of sustainable

${ }^{30}$ P. Collier, A. Hoeffler, and M. Söderman, 'Post Conflict Risks', Journal of Peace Studies, vol. 45(4), 2008, pp. 461-478; S. Shneiderman and A. Snellinger, 'Framing the Issues: The Politics of "Post-Conflict", Hot Spots, Cultural Anthropology, 24 March 2014, http://www.culanth.org/fieldsights/5oo-framing-theissues-the-politics-of-post-conflict, [accessed 28 February 2018 ].

${ }^{31}$ A. Ghani and C. Lockhart, Fixing Failed States, New York, Oxford University Press, 2009.

${ }^{32}$ Interview with left-leaning CA member who participated on the NYP Drafting Committee, 20 March 2013, Kathmandu. 
peace'. ${ }^{33}$ By creating employment opportunities, it envisioned youth participation in the 'reconstruction and economic transformation of the nation'. ${ }^{34}$ In 2008, Maoist Prime Minister Pushpa Kamal Dahal issued a directive to create the National Youth Policy (NYP), the Ministry of Youth and Sports (MYS), and broad-scale education and employment schemes.

The Maoist government garnered political capital from international brokers as well as their youth wings, despite their paternalistic agenda to 'maximize youth's productive capacities and harness them for the restructuring of the nation' ${ }^{35}$ By following the post-conflict protocol meant to ensure state legitimacy, the Maoists were demonstrating to their international interlocutors their ability to govern. Furthermore, bringing their youth wings on board to draft the NYP fulfilled the quid pro quo between the Nepali political parties and their youth wings, following the patronage tradition of securing positions for your followers once you have arrived to power. The policy formation also enabled resource governing, which established the Maoists' public authority among both the general population and their youth wings.

The political youth leaders eagerly embraced the opportunity to participate formally in state rebuilding and extend their political roles beyond contentious protest. A Drafting Committee member from the Youth Communist League explained the opportunity in this way:

You know the history of youth activism. Youth have been the vanguard of every political movement. On the streets and in the jungles we've won hearts and minds to secure our parties' position in government. Our mother party knows that is not enough. The NYP and Ministry of Youth and Sports are part of the Maoists' holistic agenda to restructure society. They know the youth must play a part and we, their youth activists, must oversee it. This is the difference between us and other parties. ${ }^{36}$

Maoist ideals around restructuring for a 'new Nepal' rhetorically framed his explanation, but he was also problematizing the history of youth's political role being limited to street activism and then being

\footnotetext{
${ }^{33}$ National Planning Commission. Three-Year Interim Plan, Kathmandu, Government of Nepal, 2007.

${ }^{34}$ Ibid.

${ }^{35}$ Based on an interview with the YSEF programme's vice chairman, 8 May 2013.

${ }^{36}$ Interview with leftist youth wing-affiliated Drafting Committee member, 27 March 2013, Kathmandu.
} 
sidelined after their political parties returned to governing. ${ }^{37}$ The post-conflict agenda which aimed to bolster public investment in order to establish the new state's legitimacy produced a particular public authority, one that simultaneously diverged from and complemented the authority of previous governments.

The composition of the Drafting Committee demonstrates, however, that the political youth leaders were not given carte blanche. Representation from other members of the power polygon, ${ }^{38}$ namely civil society and INGOs, was required to legitimate the NYP within the post-conflict agenda. Thus, there were competing agendas, all hoping to derive influence and establish public authority through the NYP. The Drafting Committee had 20 members plus a delegate from the National Planning Commission, the Ministry of Youth and Sports, and one expert. The Committee was politically skewed, as it was composed of delegates from each of the politically affiliated youth organizations (ten in total), three 'youth' Constituent Assembly members, and one student union president. Civil society representation comprised a minority, with three delegates from youth-focused NGOs and one expert of national origin representing UNIFEM. Five women participated, a little more than a fifth of the Committee. Four out of the five women were politically affiliated; the fifth was the UNIFEM representative. As a whole, the left-leaning political organizations had more representation than those from the centre and there was no conservative party representation.

The Drafting Committee was meant to be representative of Nepal's youth demographic in the spirit of samäbesh (inclusivity), which was one of the main demands of second People's Movement. The Committee dynamic demonstrates, however, the underlying challenges in uprooting endemic exclusionary processes and points to the ways hegemonic ordering is reproduced within new institutional arrangements. Those I interviewed had different standards for judging inclusivity. When I asked people why they were selected, they tended to emphasize their capabilities and their position in the political or social sector. They identified other people having been chosen based on inclusion, but not themselves. For the most part, they thought that the task force was not inclusive because they felt that people like themselves were in the minority and judged the level of inclusion based on the degree to which their views had proportional weight

\footnotetext{
${ }^{37}$ Snellinger, Making New Nepal.

${ }^{38}$ Nightingale et al., 'Fragmented Public Authority'.
} 
rather than on socio-economic categories. ${ }^{39}$ Members from the civil society sectors felt the Committee was politically dominated and those from the political sector felt it was dominated by political ideologies other than their own. The only people who thought the Committee was successfully inclusive were the left-leaning, politically affiliated, high-caste men from the hills.

The Committee demonstrated how both entrenched and new forms of marginalization have emerged, despite attempts to institute inclusion through state restructuring. The Committee included female and ethnic representation but did not satisfy inclusion quota thresholds. There were no members from the Dalit community, from the lower-economic classes, or from the geographically disenfranchised far west. But the most striking lack of inclusion was around age. Only three of the Committee members were younger than 30, no member was younger than 25 , and the majority of the members were older than 35. As I discussed in the introduction to this article, this reflects the socio-political reality of party politics in Nepal where many are considered 'youth' up until their sixties. In all the youth wing Constitutions, youth officially extends into the midforties or higher, and thus the older members of the 'youth' category are considered to be leaders who have the experience to participate in policymaking. This dynamic greatly impacted on the debate around the age designation for youth in the NYP itself (detailed further in the fourth section of this article).

The role of the donor community in the NYP drafting process was indicative of how public authority proliferated through the postconflict agenda. The degrees of criticism and enthusiasm concerning donor influence demonstrated the varying agendas of the Drafting Committee members as well as underscored the political youth leaders' eagerness to garner governing authority. Every person I spoke to denied that this foreign aid had shaped the NYP or contributed to its fruition. Rather, respondents invoked Nepal's sovereignty, asserting that only the state of Nepal could decide policies for its people. One member assured me there was no pressure; rather it was a joint commitment between the foreign friends and the political parties

\footnotetext{
${ }^{39}$ Politically left-leaning members were more likely to judge inclusion based on gender and ethnic group diversity. Only one participant from the civil society sector assessed caste diversity.
} 
to create long lasting peace'. ${ }^{40}$ Individuals from the MYS confirmed that there was no direct economic support for the task force team to draft the NYP. ${ }^{41}$ Instead, various foreign agencies provided technical support, organized workshops, and gave feedback.

The most notable foreign influence in the drafting process was the Norwegian embassy. The way its participation was perceived is indicative of the conflicting agendas of the members of the Drafting Committee. The Norwegian embassy was dedicated to shepherding the NYP through the process, with input and support from all political factions. They executed this plan through eight political youth organizations who agreed to participate: Tarai Madhesh Front; Nepal Tarun Dal; Progressive Youth Federation, Nepal; Madhesh Youth Forum, Nepal; Madheshi Youth Forum, Nepal (Democratic); Sadbhawana Youth Front; Youth Federation, Nepal; and Young Communist League, Nepal. ${ }^{42}$ The process was three-fold. The first phase involved nationwide workshops in which the political youth wings gathered input from young people on what the NYP should include, which was published in the 2008 report 'Rasstriya Yuba Niti Sujhāb Prativedan' (The NYP Recommendation Report). The second phase consisted of capacity-enhancement training for young political leaders so they could jointly institute a National Youth Employment Campaign. The third phase saw the launching of a nationwide advocacy campaign for youth employment which culminated in the publication of 'Recommendations for the National Youth Employment Policy' in 2012.

The Norwegian embassy's focus on the political youth organizations was in response to the political context in which the NYP was being drafted. It was a fraught time. Two previously warring sides were cogoverning. All factions were vying to establish their position in the new political landscape in which they all had the legitimate right to compete through democratic means; however, there was still deep distrust on all sides after a decade of civil war. Tensions were further heightened in the south after the Madheshi uprising in January 2007 in protest against a history of state domination from the north. The

\footnotetext{
${ }^{40}$ Interview with left-leaning Drafting Committee member, 7 May 2013, Kathmandu.

${ }^{41}$ Interview with MYS representative on the Drafting Committee, 2 May 2013 , Kathmandu.

${ }^{42}$ Other political organizations were invited to participate but chose not to. For instance, the student political organizations declined because they felt participation would undermine their claim to institutional independence.
} 
political youth wings were at the forefront in these political turf wars; their cadres clashed violently in areas of influence, campuses, district headquarters, and campaign rallies. The Norwegian embassy aimed to unite the leaders of all these political youth factions through a mutually beneficial project in order to tamp down acute tensions during this fraught period. ${ }^{43}$

The reception of the Norwegian embassy's role depended on the participant's position and interests. The political youth organizers felt the embassy played a key role in facilitating the policy, both in bringing the various political factions to the table and in expanding the dialogue and input to the grassroots level. They perceived the Norwegian embassy's involvement as productive because they benefited from it. Through their intention to create the conditions for collaboration, the Norwegian embassy legitimated the youth political wings by recognizing them as crucial to Nepal's post-conflict transition. The political youth wings garnered authority from foreign powers' investment in the NYP and their support for grassrootslevel programmes. The Norwegian embassy organized interactions within all 75 districts, relying on the political youth wings to coordinate these. This gave the latter the opportunity to participate in resource governance. They were given the resources to organize these programmes and chose the participants. Not surprisingly, they perpetuated the patronage tradition by prioritizing their politically active youths' attendance over the participation of non-political youth. Their new position as gatekeepers, sanctioned by the Norwegian embassy, created a positive feedback loop that reinforced the youth wings' legitimacy, agenda, and lobbying efforts on the NYP Drafting Committee, in their parties, at various levels of governance, and also elevated their stature with foreign donors.

Representatives from non-political organizations, on the other hand, were quite critical of the Norwegian embassy's support during the drafting of the NYP. The Lead International coordinator explained to me that the Norwegian embassy spent more on the eight youth wings' coordinating efforts than on the drafting and instituting of the NYP itself. ${ }^{44}$ To many NGO and INGO observers this underscored the fact that the drafting of the NYP was a political process masked as social policy. One youth NGO participant explained to me that most young

\footnotetext{
${ }^{43}$ Interview with Save the Children programme coordinator, 7 May 2013, Kathmandu.

${ }^{44}$ Interview with Lead International coordinator, 6 May 2013, Kathmandu.
} 
people were excluded and felt no ownership over the NYP because it was dominated by the agendas and priorities of political youth wings. This perpetuates the growing gap between political and non-political youth that has emerged since the institution of multiparty democracy; many young people are disconnected from politics because they feel no ownership beyond casting a vote. ${ }^{45}$ Drafting Committee members from the NGO and INGO sector argued that such foreign support enhances political parties' tendency to usurp any opportunity and space of influence in order to amass resources and power. Their criticism points to an inherent challenge within the post-conflict agenda: the difficulty of balancing stability with trying to encourage local communities to invest in state legitimacy.

This challenge was further underscored in the switching of attitudes towards foreign donor influence after the policy was drafted. Donors supported NGOs to institute the policy rather than the government or their affiliated youth wings. The politically affiliated participants were critical of this process, asserting that a single door policy should be instituted so that the government could oversee NGO activities and coordinate them with government efforts to maximize the NYP's effectiveness. The perception that donor organizations were manipulating the government through NGOs was a loss of face for the post-war government. People from the NGO and INGO sector, on the other hand, saw donors' post-policy efforts as a way to ameliorate the political dominance on the Drafting Committee and for the NYP to have a social impact.

Attitudes towards foreign donors' influence were fluid throughout the drafting and instituting stages of the NYP. The perspectives of both political- and civil-affiliated Drafting Committee members changed as the policy took shape. The shift in attitudes underscores the role of external actors in legitimating governing practices in postwar Nepal. Both political and civil society actors leveraged the support they received from donors and international actors in order to claim authority for their agendas. Yet at the same time, a majority of them intimated to me that the international actors' constant shift in support and priorities seemed like a capricious attempt to dictate who had the right to govern, represent, and allocate resources. In other words, when foreign influence did not suit their particular agenda, they dismissed

\footnotetext{
${ }^{45}$ A. Snellinger, 'A Crisis in Nepali Student Politics?: Analyzing the Gap Between Politically Active and Non-Active Students', Peace and Democracy in South Asia Journal, vol. 1 (2), 2005, pp. 18-43.
} 
REARTICULATING AUTHORITY IN POST-WAR NEPAL 1061 it as interference beyond the scope of establishing their post-conflict state's legitimacy.

\section{The National Youth Policy: political or policy document?}

Although the NYP was both a post-conflict pacification measure and source of political patronage, it was the Committee dynamic itself that determined the document. I now turn to the different ways in which the political agenda dominated the drafting process of the NYP and dictated the language of the policy document.

Democratic theorists have established that the process by which decisions are made, namely who speaks and who is heard, are integral to any deliberation process. ${ }^{46}$ This is certainly true in Nepal with its exclusionary history. ${ }^{47}$ Thus I made sure to ask participants about the Drafting Committee interactions and dynamics. What emerged from their responses was that the disciplinary environment of policy drafting led to different types of clashes and conflict wherein the politics of exclusion took on a different optic but was also reminiscent of traditional forms of structural violence.

The NGO and INGO sector participants critiqued the youth wing participants for their domineering approach. They also dismissed their disorganization (ranging from high rates of absenteeism, tardiness, as well as refusal to stick to any meeting agenda), arguing that it kept the Committee meetings from being as robust and productive as they had hoped. They were disappointed that the Committee chair or ministry members did not take a more assertive role in chairing the meetings to ensure everyone had equal opportunities to express their views. This environment kept many participants from debating the most contentious issues and speaking out against the youth wings' dominant caucus.

${ }^{46}$ B. Benhabib, Democracy and Difference, Princeton, NJ, Princeton University Press, 2002; C. Mouffe, On the Political, London, Routledge, 2005; L. Pellizzoni, 'Legitimacy Problems in Deliberative Democracy', Political Studies, vol. 51(1), 2003, pp. 180196; Rancière, Disagreement; J. Valadez, 'The Implications for Incommensurability for Deliberative Democracy'. In Deliberative Democracy in Practice, D. Kahane, D. Weinstock, D. Leydet, and M. Williams (eds), Vancouver, UBC Press, 2010, pp. $15^{6-173}$.

${ }^{47}$ P. Jha, Battles for the New Republic: A Contemporary History of Nepal, Delhi, Aleph Press, 2014; M. Lawoti, Towards a Democratic Nepal: Inclusive Political Institutions for Multicultural Society, New Delhi, Sage Publications, 2005; M. Malagodi, Constitutional Nationalism and Legal Exclusion: Equality, Identity Politics, and Democracy in Nepal, Oxford, Oxford University Press, 2013. 
The youth wing participants' response regarding the Committee dynamic was starkly different. None of them felt any one faction had dominated the meetings. A few expressed surprisingly similar explanations, saying that everyone had equal space to raise their voice during Committee meetings. Those who did not speak up were viewed as 'lacking the capacity'. In their view, it was personal inadequacy rather than an organizational deficiency that kept people from actively participating. ${ }^{48}$

I attribute the discrepancy between these two views to a clash of institutional culture between the political and the professional sectors regarding what is the appropriate mode of interaction for deliberative discussions. NGO and INGO members were appalled by the political participants' aggressiveness: shouting people down, cutting them off, and derailing the discussion onto completely different topical tangents. This deliberative style, however, succeeds in Nepali politics where one must take an assertive, entitled stance that is rarely socially acceptable for most people except high-caste men. ${ }^{49}$ When women embody this resolute stance, they are dismissed as 'crowing hens'. When individuals from other castes or ethnic backgrounds stand their ground, they are often dismissed as being obsessed with the single issue of marginalization. ${ }^{50}$ Thus, only those from the privileged subjectposition can presume that, since everyone has the 'right' to speak, then things are equal within the interaction. There is, however, a difference between an abstract right and whether people feel empowered to assert that right.

The way this played out on the NYP Drafting Committee was indicative of who ended up endorsing the policy and who did not. Those from the NGO and INGO sectors did not endorse the policy nor did two of the politically affiliated women, due to the outcome of the debate over the age range of youth. These women explained to me that not endorsing the document was ultimately the most effective way to make their voices heard. Here we see how pre-existing caste and gender power relations order both the terms and techniques of deliberation. ${ }^{51}$ The deliberative style that triumphed in this bureaucratic space was that of the high-caste male elite, which is not an embodiment

\footnotetext{
${ }^{48}$ Based on interviews with Drafting Committee members, 20 March 2013, 31 March 2013, 28 April 2013, and 7 May 2013, Kathmandu.

${ }^{49}$ Snellinger, 'The Production of Possibility'.

${ }^{50}$ Ibid., p. 196.

${ }^{51}$ E. Laclau and C. Mouffe, Hegemony and Socialist Strategies: Towards a Radical Democratic Politics, London, Verso, 1985 .
} 
REARTICULATING AUTHORITy IN POST-WAR NEPAL 1063 appropriate for just anyone to embrace. Ultimately, the only way for these women to be heard was to opt out, thus perpetuating the structural violence that determines who can speak and what modes of speech resonate. ${ }^{52}$

The policy itself is a product of compromise between multiple objectives and vying agendas informed by different ideologies. It is long on rhetoric and short on particulars. It lacks specificity on strategies and action plans, nor is there instruction for budget allotments to fulfil the policy's objectives. The first quarter of the policy outlines the need for a national youth policy. It opens with the assertion,

Given that the youths are the agent of economic, social and political change, the central need of this time is to specially address this class by a national policy and forge their involvement in the nation building. The youths have rendered an outstanding contribution to every political change, founding of democracy and other social movements in Nepal. The peaceful popular movement, decade-long armed conflict, Madhesh movement, Tharuhat movement as well as movements for identity and recognition, which took place in the past, have raised a demand to specially address the existing situation of the youths. The need of a policy on youths has, therefore, increased. ${ }^{53}$

This language demonstrates how important it was to memorialize the political youth's contentious politics as a contribution to national development. A Youth Communist League participant explained, 'It was not drafted by technocrats. Instead, it was drafted by the youth who had played active role in the course of the People's War and mass movements. It has incorporated many issues that matter to us. ${ }^{54}$

The issues that matter to them are outlined in the next half of the policy through a detailed list of 17 priority areas: basic rights to livelihood; education; social security; youth empowerment and leadership development; employment, both domestic and foreign; social and cultural participation; youth mobilization; health and family welfare (HIV/AIDS, malnutrition, healthy lifestyle, mental health); culture, sports, and entertainment; drug abuse; human trafficking; environment and sustainable development; science and technology; sustainable peace-building and conflict transformation; equitable development; special group priorities; and partnerships. The policy does not provide guidelines for addressing these multiple objectives,

\footnotetext{
${ }^{52}$ Rancière, Disagreement.

${ }^{53}$ Ministry of Youth and Sports, National Youth Policy, Kathmandu, Government of Nepal, 2010.

${ }^{54}$ Interview with leftist youth wing-affiliated Drafting Committee member, 27 March 2013, Kathmandu.
} 
but instead offers vague suggestions about launching programmes, building partnerships, enhancing capacity, enforcing laws, taking legal and social initiatives, and so on. In the last section-monitoring and evaluation-the policy states that the Ministry of Youth and Sports (MYS) shall serve as the mechanism to ensure these priority areas are addressed by all government ministries. The language, in other words, formalizes the MYS as a coordinating ministry.

While Nepal was applauded for drafting an NYP, the Policy was also criticized for its lack of specifics. The UN-funded Asia-Pacific Interagency Group on Youth warned that the vagueness of the policy's language would be a major obstacle in implementing Nepal's NYP. ${ }^{55}$ However, the external criticisms did not take into account the postconflict environment in which the NYP was put together. One leftleaning CA member on the Drafting Committee clarified this in the following way,

This was not the agenda that was prepared by the youth. This was the draft prepared by the youths who were affiliated to political parties. It was due to this that there was vagueness in the language. Every ideology wanted to be represented ... this agenda must be linked to our political agendas since none of the nation's problems can be solved until political problems are solved. This is how politics became the central focus. The Youth Policy put politics as the focus. ${ }^{56}$

His explanation makes it clear that political agendas took priority over specific action plans. This approach is akin to the way Nepali political coalitions have outlined common minimum programmes over the last two decades. ${ }^{57}$ Political agreements have needed to be vague in order to forge the joint ownership necessary to maintain the coalition. If those agreements were more specific, the incommensurability of the two previously warring sides would become obvious and develop into an obstacle to the coalition. The political youth took the same tack when writing the NYP because they saw the document as formalizing a precedent to work towards their envisioned political goals.

One participant said the language is vague because it was felt that everyone had 'to feel ownership' over the document, thereby making

\footnotetext{
${ }^{55}$ Asia-Pacific Interagency Group on Youth, Investing in Youth Policy, New York, UNICEF, 2011.

${ }^{56}$ Translation of an interview with a Constituent Assembly member on the NYP Drafting Committee, 2o March 2013, Kathmandu.

${ }^{57}$ Snellinger, 'Production of possibility'.
} 
REARTICULATING AUTHORITy IN POST-WAR NEPAL 1065 it a hodgepodge of political rhetoric. ${ }^{58}$ A number of different political ideologies were represented on the task force team and everyone insisted their views be represented. This caused endless debate over terminology. Squabbles between Committee members over whether to use communist or democratic political language would last for weeks. For instance, there was an ongoing debate between the Maoists and democratic forces on whether to use 'Loktantra' (Democracy) or 'Jantako Loktantra' (People's Democracy). The Maoist participants were keen to use the NYP to enshrine the apex of their political agenda, Jantako Loktantra. The democrats embraced semantics to eschew the Maoists' overt political agenda, arguing that 'Loktantra' implied 'people' in the root lok, which means 'folk', ${ }^{59}$ and therefore 'jantako loktantra' was redundant. Loktantra won out with the support of the non-political members and centre-leaning political members. Nonetheless, the debate carried on until the end. This is just a small example of how the Maoists' political agenda was stymied during the post-war transition, despite their recent political victories.

Another reason cited for the lack of clarity was that the scope of the policy was a timeless manifesto meant to promote a political vision for society. One member explained, 'Since this is a policy after all, it is for the present and the future. We wanted to ensure that it can be implemented in the present but also in the future. We wanted the policy to capture what we envision for our future society. ${ }^{60}$ Her statement strengthens the assertion made by the NGO and INGO sector participants: this policy was first and foremost a political document. If it were meant to be otherwise, then the external political experts would have had more input; it therefore reads like a political plan that the MYS will be able to institute in both the present and the future. A civil society youth member explained to me that the political youth wing participants saw their policy suggestions as a threat.

The political youth leaders successfully dictated the terms of the NYP. It is an aspirational document, an official testament to their role in Nepal's political development, and a decree for comprehensive

\footnotetext{
${ }^{58}$ Interview with Drafting Committee member, 28 April 2013, Kathmandu.

${ }^{59}$ The root lok has a number of different definitions, including: the world, the universe, region, society, people, folk, and mankind. But the definition attributed to the root in loktantra is folk/people, thus translating to folk/people's rule.

${ }^{60}$ Translation of an interview with Drafting Committee member, 28 April 2013, Kathmandu.
} 
youth accommodation. The only clear directive the policy sets out is to institute a National Youth Council in order to implement this policy. It states,

An autonomous and executive national youth council shall be formed by a separate Act for the implementation of this Policy. This council shall consist of representatives of the concerned bodies, representatives of youth organizations of political parties and office-bearers appointed by the Government of Nepal. The council shall have an organizational structure from the centre to the local level ... The council shall coordinate, harmonize, and facilitate programmes relating to youths launched by the governmental, non-governmental and private sector. Structures such as [a] youth information and research centre, youth counselling and service centre, youth employment promotion centre shall be established in pursuant of this Policy, as per the need of youths at the local level. Law, as required, shall be made for the operation of [the] business of the council and the sub-ordinate bodies, and financial and administrative provisions shall be made.

The agenda to garner a new sphere of influence in post-conflict Nepal's governing apparatus comes through quite clearly in this statement. The National Youth Council is meant to establish the policy agenda that will address all the priority areas the NYP outlines.

A MYS bureaucrat who participated in redrafting the endorsed policy into an action plan admitted that they were under a lot of pressure to retain the political agenda. ${ }^{61} \mathrm{He}$ said that this was problematic because a national policy should not represent any party agenda but instead should be coherent with other state policies. Politically motivated policy becomes null once the government, and thus political priorities, change. As demonstrated in the penultimate section of this article, the policy's political aspirations pulled it further and further out of the domain of the political actors as ministerial bureaucrats turned it into an action plan they could institute.

\section{What is youth? And who speaks for youth?}

The most contentious issue contained in the policy content demonstrates how authority is established through crafting subjectivity within a governing terrain; in other words, an attempt to order social relations. The issue was the age range defining 'youth'.

\footnotetext{
${ }^{61}$ Interview with former MYS bureaucrat who redrafted the endorsed NYP to align with other policy documents, 15 June 2013 , Kathmandu.
} 
REARTICULATING AUTHORITY IN POST-WAR NEPAL 1067

The policy, ultimately, defines youth as ages 16-40, which reflects the dominance of the affiliated political youth wing participants. The non-political sector advocated for the upper age limit to be 29. They reasoned, like the 2002 policy draft, that it needed to surpass the UNsanctioned limit of 24 years of age due to the scarcity of economic and educational opportunities in Nepal. The original draft set the upper limit at 35. However, the youth wing participants affiliated with the five main parties argued for 45 , based on their own Constitutions. ${ }^{62}$ Many different national and international sources were consulted to advocate for the precedents of different age caps. Those in favour of setting the age cap at 40 argued that it was consistent with political youth wing policies since Panchayat rule. ${ }^{63}$ The National Planning Commission, however, defines youth as $15^{-29}$ for budgeting purposes. The age limit for recruitment in the Nepal Army, police, and armed forces varies from 22 to 25 years of age. The upper limit to sit the Public Service Commission and Education Service exams is 35 .

Many hours of debate ensued over the age range, with outside lobbying too. Based on the breakdown of support, the Committee agreed to compromise and cap the upper age limit at 35. However, the final draft that was presented to the Ministerial Council for endorsement set the age cap at 40 . I was informed that the upperage limit was determined by external political lobbying because it did not garner majority support from the Drafting Committee itself. Chairman Pandey refused to change the 16-40 age designation and it was approved by the Ministerial Council. The policy does state, however, that it can be altered according to future population changes. ${ }^{64}$

Those who supported an age cap of 29 were thoroughly disappointed and seven of them did not endorse the final policy. One critical individual explained the youth wings' motivation as such,

${ }^{62}$ These were the youth wings affiliated to the Nepali Congress, UML, Maoists and Peasants and Workers Party of Nepal, and UML-United Front.

${ }^{63}$ Interview with MYS representative on the Drafting Committee, 2 May 2013, Kathmandu.

${ }^{64}$ The 16-40 age range was not altered in the National Youth Council Act that was passed in August 2015 nor in the Youth Vision 2025, the MYS's ten-year strategic working plan for the National Youth Council. This is despite the suggestions of the task force who guided the MYS in drafting the National Youth Council Act and Youth Vision 2025 working plan. The task force chairman explained to me there was pressure from a sub-sector of the parliamentarians not to lower the upper-age limit. 
The youth leaders, who represented the political parties, they didn't fall in the 16-29 age category; they belonged to $35^{-} 5^{\circ}$ or even 60 age demographic. It seems to me that they were drafting the policy for themselves. They tended to think ... for their own sake rather than for the youth throughout the nation. For this reason, they took a very strong stance. The preliminary draft had the provision of $16-35 \ldots{ }^{65} \mathrm{We}$ opined that it is just like feeding the food meant for an infant to a 22-year old person. We disagreed with it. That was the debate. I wrote a note of dissent on it. They even said that I must be punished for this. ${ }^{66}$

Four of the dissenting participants boycotted the remaining meetings once they realized they could not change things. The other three continued to attend, but said they stopped participating.

There were three main concerns regarding the 16-40 age range. The first was that it incorporates up to three generations, including parent and child, within the same demographic category. ${ }^{67}$ Secondly, the resources allocated for youth programming will be spread thinner and will inevitably dilute the impact of policies geared towards young people. The third concern was raised by international agencies because the age range throws Nepal's official budgetary and policy statistics off from transnational donor norms. According to the introduction of the NYP, Nepal's youth (16-40) comprises 38.8 per cent of the population. ${ }^{6,69}$ However, the percentage of Nepal's youth population according to the UN standard $\left(15^{-24}\right)$ is 19.97 per cent, and it is 27.82 per cent of the population according to the Nepal Planning Commission and the International Labour Organization's youth target group $\left(15^{-29)}\right)^{70}$ Thus the NYP throws off the uniformity of prescribed norms, emphasizing the socially constructed and relative underpinnings of the youth category. ${ }^{71}$

${ }^{65}$ Translation of an interview with Drafting Committee member, 28 April 2013, Kathmandu.

${ }^{66}$ Interview with Drafting Committee member, 28 April 2013, Kathmandu.

${ }^{67}$ Asia-Pacific Interagency Group on Youth, Investing in Youth Policy.

${ }^{68}$ Government of Nepal, Ministry of Youth and Sports, National Youth Policy.

${ }^{69}$ According to the 2011 national census, 40.3 per cent of Nepal's population is between the ages of 16 and 40: http://unstats.un.org/unsd/demographicsocial/census/documents/Nepal/Nepal-Census-2011-Vol1.pdf, [accessed 30 March 2017 .

${ }^{70}$ Government of Nepal, Central Bureau of Statistics, National Population and Housing Census, Kathmandu, National Planning Commission Secretariat, 2012.

${ }^{71}$ V. Amit-Talai and H. Wulff (eds), Youth Cultures: A Cross-cultural Perspective, New York, Routledge, 1995; M. Bucholtz, 'Youth and Cultural Practice', Annual Review of Anthropology, vol. 31, 2002, pp. 525-552; J. Cole and D. Durham (eds), Generations and 
The logic of those who supported the 16-40 demographic is shaped by the everyday reality of politics in Nepal, where there is little opportunity for people to advance. In Nepali politics there is an endemic mistrust of young people's abilities in politics, causing elders to hold onto their leadership positions and not cede responsibility to their juniors, which perpetuates the stereotype that young people are inexperienced. One NYP participant aptly noted, 'We have a disease in politics, one is said to be youth unless he/she holds a position. ${ }^{, 72}$ Thus, the category of youth has been extended to incorporate people of older generations into what I call 'micro-categories of emergence and waiting'. ${ }^{73}$ Other scholars have noted techniques of waiting that young people employ in order to cope with the socio-economic status of delayed adulthood. ${ }^{74}$ This is particularly prevalent in the global South where a gap exists between people's social realities and their aspirations, trapping populations in an anxious 'not now, not yet' state. ${ }^{75}$ Understood within this context, the youth wing members' endorsement of 40 as the upper-age limit of the youth demographic is a proactive attempt to deal with socio-political structures beyond their control.

All of the youth wing participants gave socio-cultural justifications for their position on the upper age limit. One participant explained that since the food, culture, environment, and family dynamics are different in Nepal, they don't feel the need to uphold this international standard. ${ }^{76}$ A Maoist participant explained that Nepal was still fighting the remnants of feudalism and is just preparing to enter

Globalization: Youth, Age, and Family in the New World Economy, Bloomington, Indiana University Press, 2007.

${ }^{72}$ Translation of an interview with Drafting Committee member, 28 April 2013, Kathmandu.

${ }^{73}$ Snellinger, "Yuba, Hamro Pusta!".

${ }^{74}$ Jeffrey, Timepass; C. Katz, Growing Up Global: Economic Restructuring and Children's Everyday Lives, Minneapolis, University of Minnesota Press, 2004; D. Mains, 'Neoliberal Times: Progress, Boredom, and Shame Among Young Men in Urban Ethiopia', American Ethnologist, vol. 34(4), 2007, pp. 659-673; A. Masquelier, 'The Scorpion's Sting: Youth, Marriage and the Struggle for Social Maturity in Niger', Journal of the Royal Anthropological Institute, vol. 11(1), 2005, pp. 59-83; M. Ralph, 'Killing Time', Social Text, vol. 26, 2008, pp. 1-29.

${ }^{75}$ D. Chakrabarty, Provincializing Europe: Postcolonial Thought and Historical Difference, Princeton, NJ, Princeton University Press, 2000, p. 256. Quoted in Jeffrey, Timepass, p. 12.

${ }^{76}$ Interview with democratic youth wing-affiliated Drafting Committee member, 31 March 2013, Kathmandu. 
into capitalism. ${ }^{77}$ His explanation echoed another respondent who admitted that Nepal had not reached the European standard and therefore finds itself in the phase of development where young people aged between 15 and 24 still depend on their parents and therefore cannot play a significant role in policymaking. ${ }^{78}$ Another member explained that people are not given guardianship responsibilities in their families until after the age of 45 and this is why the 16-40 age range is necessary. ${ }^{79}$

The benefits, they explained, were that the youth demographic would command a larger representation in different agencies and this would combat older people hijacking the resources and privileges meant for young people. This larger age range would legitimize the position of the youth because, as one member explained to me, Nepal has a tradition of dismissing young people because they are not mature and do not have life experience. ${ }^{80}$ Another political youth leader asserted, 'the $15^{-24}$ age range consists of the youth who have just passed their teenage years. We doubt that this age group may be able to give a good performance. Therefore, we had a request to include more "matured" persons. ${ }^{81}$ Their responses highlight the degree to which they have internalized the age bias that is endemic in Nepali politics. A bureaucrat who represented the MYS supported this stance, saying that those aged $35^{-4}$ o have more experience and can therefore think more constructively than those in the $15^{-24}$ age range; however, he quipped, the elder youth also have a tendency to dominate the younger youth. ${ }^{82}$

The youth wing participants were thoughtful about why the $16-$ 40 age range was beneficial. Nevertheless, they all were clear about what motivated them: an official place for them to develop political leadership through policy oversight. A YCL participant's explanation aptly summarized their agenda,

\footnotetext{
${ }^{77}$ Interview with leftist youth wing-affiliated Drafting Committee member, 27 March 2013, Kathmandu.

${ }^{78}$ Interview with former youth wing president who served on the Drafting Committee, 10 April 2013, Kathmandu.

${ }^{79}$ Interview with democratic youth wing-affiliated Drafting Committee member, 31 March 2013, Kathmandu.

${ }^{80}$ Interview with former youth wing president who served on the Drafting Committee, 10 April 2013 , Kathmandu.

${ }^{81}$ Translation of an interview with former youth wing president who served on the Drafting Committee, 1o April 2013, Kathmandu.

${ }^{82}$ Interview with MYS representative on the Drafting Committee, 2 May 2013, Kathmandu.
} 
We reasoned we can target this $(16-40)$ age range to develop political leadership. As for UN provisions, their underlying logic for determining the age range is meant for providing services whereas we have political reason behind it. We felt that it should be defined politically, too. Finally, we made it this age range in order to ensure the involvement of youth from the parties' sister organizations. ${ }^{83}$

The youth wing participants were fearful of elders stepping in to take over the leadership duties of the NYP if they set the upper age limit too young. Having seen this happen regularly in their political parties, they argued that the leadership level of the National Youth Council—which will oversee the work of the MYS in all the districtsshould be reserved for people aged $30-4 \mathrm{O}$, so that those with the most experience will be working as youth and for youth. ${ }^{84}$ People aged 2030 could gain experience by assisting in instituting policy, and the benefits (resource allocation) would go to the teenagers (aged 1620). ${ }^{85}$ It is clear that these participants envisioned the policy to be implemented in the same way in which their political organizations operate-as a tiered age-hierarchy in which leadership is reserved for elders. The obvious downside in how this has played out for the non-political sector is that it has further entrenched a political precedent that has alienated young people: older people speaking for them.

\section{The limits of policy implementation in post-war transition}

The Drafting Committee members represented the political, civilsociety, and donor sectors, and thus came to the drafting process with their own practical and ideological aspirations for the National Youth Policy. All the actors tried to leverage the authority of government policy for their own agendas. Unfortunately, none of these sectors unified to share joint ownership of any one stage of the NYP development process. Members from the NGO and INGO sector did not feel ownership during the drafting process because political agendas dominated. Some have begun to coordinate with the MYS

\footnotetext{
${ }^{83}$ Interview with leftist youth wing-affiliated Drafting Committee member, 27 March 2013, Kathmandu.

${ }^{84}$ Interview with former youth wing president who served on the Drafting Committee, 10 April 2013, Kathmandu.

${ }^{85}$ Interview with leftist youth wing-affiliated Drafting Committee member, 27 March 2013, Kathmandu.
} 
and donors to establish institutionalizing mechanisms that will stymie political party infiltration in the oversight of the youth policy. Through institutionalization, they hope to free the NYP from its limitations as a political document. ${ }^{86}$

This section outlines how the political youth's ability to establish a foothold in policy implementation was limited by the ever-shifting context of post-war transition in which the NYP was developed. Due to the inconsistent political dynamics of state reconstruction, different priorities dictated each stage of policy development. During the drafting stage the central priority was to court political youth to ensure the peace and stability necessary to carry out the postconflict agenda. By the time the policy was approved in 2010, the Maoists were out of power and the governing party, CPN-UML, was not willing to squander political capital on a Maoist-initiated policy. Instead of putting the policy to a vote in parliament it was passed by the Ministerial Council. Without a parliamentary mandate or the governing party's support, the NYP did not have the momentum to establish the political youth's vision and instead fell into the domain of the Ministry of Youth and Sports.

The Ministry has been slow to institute the NYP since the Ministerial Council approved it in 2010. As a new ministry with scant political backing and a small operating budget of less than 1 per cent of the government's annual budget, it is considered a backwater ministry with little opportunity to influence government procedure. MYS bureaucrats shared with me how being pressured by competing agendas from the political, civil society, and donor sectors to institute the NYP effectively has stretched them thin. And, of course, these bureaucrats have their own agendas and logic, especially in terms of preserving the boundaries of their own bureaucratic authority.

The Ministry's main role has been to coordinate youth-focused programmes across the ministries and different government sectors to ensure that they are abiding by the NYP directives and to curb redundancies. The MYS representative on the Drafting Committee informed me that even the National Planning Commission's ThreeYear Plan was devised within the guidelines of the NYP. In this regard, the MYS is similar to the Ministry of Women and Children: it is more of a lobbying and coordinating mechanism than a ministry

\footnotetext{
${ }^{86}$ Interview with NGO sector participant on the Drafting Committee, 29 April 2013 , Kathmandu.
} 
REARTIGULATING AUTHORITY IN POST-WAR NEPAL 1073

with a discrete, centralized jurisdiction. The other efforts the MYS has focused on is devising a Youth Responsive Budget in cooperation with UNFPA and 17 different ministries; establishing six model youth information centres in the five development regions with Save the Children, the Youth NGO Federation (Nepal), and Yatra; and drafting an NYP Action Plan of Implementation with UNFPA and UNICEF. When asked why they had not established the NYG in 2013, I was told they were designing the implementing and monitoring mechanisms required by ministerial protocol first. ${ }^{87}$ In 2015 , five years after the NYP was approved and seven after it was drafted, the National Youth Council Act was finally passed, along with a 10-year strategic plan called Youth Vision 2025. The NYC, however, had yet to be instituted.

The political youth Drafting Committee participants who endorsed the NYP were disappointed. The reigns of policy oversight had been taken away from them and handed over to the bureaucratic machinery they see as perpetuating the very formations of power they rebelled against. This was clear to them when the MYS devised the strategic plan before forming the NYG. ${ }^{88}$ They argued the NYP expressly stated that the NYG should be instituted first to play a central role in devising the action plan. One youth wing member expressed his frustration in this way,

It has become like a mirage (mrigatrishna). It contains so many beautiful things. It would have been nice had the government fulfilled at least the minimum demands we had made. We had requested the government to form a National Youth Council. At least there should be an executing agency overseen by us. It was not formed. We had also recommended forming youth councils in every district and we had the expectation that the government would allocate a budget for them. ${ }^{89}$

The political youth leaders framed their own feelings of alienation from the governing process within the political history of youth marginalization in Nepali politics. Ultimately, the little authority they accrued from policy formation seems shallow compared to what they achieved through contentious politics.

\footnotetext{
${ }^{87}$ Interview with MYS representative on the Drafting Committee, 2 May 2013, Kathmandu.

${ }^{88} \mathrm{~A}$ former MYS bureaucrat predicts that if the National Youth Council is not formed, then the NYP will be of no use as time passes (khera janchha). Interview, 15 June 2013 , Kathmandu.

${ }^{89}$ Interview with leftist youth wing-affiliated Drafting Committee member, 3 April 2013 , Kathmandu.
} 


\section{Conclusion}

During the drafting process, political youth leaders tried to establish themselves in the post-war transition. They used the rhetoric of youth marginalization and disenfranchisement in an attempt to govern on behalf of the youth. Due to the role they played in re-establishing their political parties in government, they felt entitled. The National Youth Council was the key element of a policy that was meant to ensure their governing authority and provide young leaders with a role in service distribution and resource allocation. They pursued a traditional political strategy to secure their political position and ensure their ability to shape the future society they envision.

Although the political youth felt they were establishing a new agenda, the way they approached policy formation unwittingly reproduced hegemonic ordering in a few ways: it perpetuated the internal hierarchy within the political youth dynamic, it exacerbated the widening gap between political and non-political youth, and it stoked traditional forms of caste and gender marginalization. Furthermore, their single-minded intent to craft a political document pulled it further away from the political arena and into the bureaucratic purview, exacerbating the disjuncture between policy formation and policy implementation. Of course, as I demonstrate in the last section of this article, much of this was outside their control since the policy was developed in the context of ever-shifting priorities. Thus the development of the NYP underscores that political transition is not finite but an emergent process that is constantly altered by different agendas. The drafting and instituting of the NYP demonstrate what Klem and Suykens argue in the Introduction to this special issue, 'public authority is often derived from representing state institutions, securing access to state resources, and confirming the state's discourses of order and legitimacy, but it may also stem from the ability to withstand the state, to transgress or bend state rules, to unleash trouble and run amok ${ }^{90}$

The history of Nepal's National Youth Policy underscores what is at stake in post-conflict state restructuring. Although inspired by a transgressive andolan agenda, state restructuring has been an attempt to establish a new 'policing logic' through 'post-democratic' consensus. Policy formation was employed as a central device to crystallize a new

\footnotetext{
${ }^{90}$ Suykens and Klem, 'The Politics of Order and Disturbance'.
} 
REARTICULATING AUTHORITY IN POST-WAR NEPAL 1075

set of power relations and distribution systems. But as the outcomes of the NYP demonstrate, policy is both an artefact that produces and is produced by hegemony. ${ }^{91}$ It is difficult to produce a new hegemonic order when competing agendas and logics are forced to compromise. A lament from the Maoist Youth Communist League Drafting Committee member captures how little they had gained through their formal participation in policy formation,

It is like this ... Nepal's politics has forever remained sort of incomplete. Revolution takes place but it does not bring the social and economic changes needed ... revolution has not been able to make a leap forward. I cannot tell you for certain if this youth policy will bring any big change. We thought it might. But it is a product of compromise between revolutionary forces, Nepal's People's Revolution, and status quoists with their so-called capitalistic democratic revolution. We now see this is not the way to bring big change. ${ }^{92}$

The question remains: to what degree will the policy 'harness youth in the restructuring of the nation'?93 Or will youth disenfranchisement cause the political pendulum to swing back to andolan-for this has been the political cycle in Nepal.

${ }^{91}$ C. Mouffe, The Democratic Paradox, London, Verso, 200o, p. 49.

${ }^{92}$ Interview with leftist youth wing-affiliated Drafting Committee member, 27 March 2013, Kathmandu.

${ }^{93}$ Based on an interview with the YSEF programme's vice chairman, 8 May 2013. 